\title{
INVESTIGATION OF THE SWITCHING AND CARRIER RECOMBINATION CHARACTERISTICS IN THE PROTON IRRADIATED AND THERMALLY ANNEALED Si PIN DIODES
}

\author{
A. Uleckas, T. Čeponis, A. Dzimidavičius, E. Gaubas, J. Pavlovas, and K. Žilinskas \\ Vilnius University Institute of Applied Research, Sauletekio 9, LT-10223 Vilnius, Lithuania \\ E-mail: eugenijus.gaubas@ff.vu.lt
}

Received 5 February 2010; revised 4 May 2010; accepted 17 June 2010

\begin{abstract}
Results of comparative study of deep level transient spectroscopy and of reverse recovery time $\left(\tau_{\mathrm{RR}}\right)$ of PIN diodes with $\delta$ and triangle-shape radiation defect distribution profiles are presented. FZ silicon PIN diodes were irradiated by varying proton fluence in the range of $10^{13}-10^{15} \mathrm{p} / \mathrm{cm}^{2}$ and keeping fixed or gradually changing protons energy in the range of $2-2.7 \mathrm{MeV}$ to introduce different profiles of radiation defects. Variations of the functional characteristics of PIN diodes containing different density of radiation defects and their distribution profiles are compared. Isochronous $24 \mathrm{~h}$ annealings in the temperature range of $80-400^{\circ} \mathrm{C}$ have been performed in order to suppress the detrimental carrier generation centres.
\end{abstract}

Keywords: reverse recovery time, deep level transient spectroscopy, radiation defects, carrier lifetime, Si PIN diodes

PACS: 61.72.Ji, 61.82.Fk, 72.40.+w

\section{Introduction}

High switching rate is the essential parameter within operational characteristics of the high power PIN rectifiers. Reverse recovery time and softness of recovery transients strongly depend on the location of the enhanced recombination centres and on the profile of distribution of these centres within a PIN diode base region [1]. Irradiation techniques combined with heat treatment procedures can be a precise tool to govern the location and densities of fast recombination centres $[2,3]$. Together with beneficial features the irradiations also cause the enhanced leakage currents and forward voltage drops [4]. For this reason it is important to optimize a trade-off between the dynamic and static device parameters $[1,3,5]$.

In this work, FZ Si diodes were irradiated by 2.0 $2.7 \mathrm{MeV}$ energy protons to position either a $\delta$-shape layer or a triangle profile of defect distribution within a PIN diode base region. Density of radiation defects has been varied by manipulation of the irradiation fluences in the range from $7 \cdot 10^{12}$ to $7 \cdot 10^{14} \mathrm{p} / \mathrm{cm}^{2}$. Diodes were isochronously annealed after irradiation to optimize a trade-off between reverse recovery time, forward voltage drop, and leakage current. A deep level transient spectroscopy (DLTS) has been employed to identify radiation-induced defects and to determine their im- pact on the change of the electric parameters after annealing. The concerted measurements of the reverse recovery transients have been employed to evaluate the operational parameters of the irradiated and heat processed PIN diodes.

\section{Measurement techniques}

Capacitance deep level transient spectroscopy (C-DLTS) measurements have been performed by using a commercial spectrometer DLS-82E, to identify carrier generation centres. A temperature scan regime has been employed to register spectra of deep traps.

The reverse recovery transients have been examined by using an industrial tester designed to measure the reverse recovery time $\tau_{\mathrm{RR}}$ values in the range from $10 \mathrm{~ns}$ to $4 \mu \mathrm{s}$. Reverse recovery time $\tau_{\mathrm{RR}}$ in diodes is commonly determined at 10 or $25 \%$ level relatively to the reverse recovery current $I_{\mathrm{Rmax}}$ peak value. Forward current peak values within pulses of duration of $30 \mu \mathrm{s}$ during the reverse recovery time measurements can be varied within a range of $0.5-15 \mathrm{~A}$. The rate of current drop $\mathrm{d} I / \mathrm{d} t$ is usually varied in the range of $10-50 \mathrm{~A} / \mu \mathrm{s}$. The reverse recovery time and the forward voltage drop $V_{\mathrm{F}}$ have been measured by this TD2050 tester. 


\section{Results and discussion}

The highest operational frequency of PIN diodes is limited by the reverse recovery process. Time required to extract minority carriers injected into base region during conductive state after it is turned to off-state determines the reverse recovery duration $\tau_{\mathrm{RR}}$. In order to reduce $\tau_{\mathrm{RR}}$ and to increase hereby the switching speed of a rectifier, the particular recombination centres are desirable, those that would cause short carrier lifetimes at high injection conditions while keeping rather long carrier lifetimes in the regime of low excess carrier density. However, fast carrier capture rate determines also a diode leakage current $I_{\mathrm{L}}$ due to thermal emission of the captured carriers within the space charge region by deteriorating the static characteristics of the reversely biased PIN diode. Therefore, deep levels of a rather large carrier capture cross-section and of special location within the band-gap are required. Few radiation defects in the wide nomenclature of their species can be desirable candidates that satisfy the requirements mentioned. An important dynamic characteristic of PIN diodes is the switching softness, determined by a ratio of durations ascribed to a rising and to a relaxation component within a reverse recovery pulse transient [1]. Soft reverse recovery is a desirable parameter in order to avoid an inductive current, which induces voltage peaks in the external circuitry [1]. The parameter of switching softness is also determined by the location of layers of enhanced recombination relatively to a metallurgical junction. Lower excess carrier instantaneous density at the blocking junction leads to faster and softer reverse recovery of PIN diode. But the increase of material resistivity (within layers of the enhanced recombination nearby a junction) leads to a forward voltage drop, which is detrimental to functional characteristic of PIN diode. Large forward voltage drop is a reason of unacceptable energy dissipation in the diode base region. Forward voltage drop $V_{\mathrm{F}}$ on PIN diode depends on the ratio $d / L_{\mathrm{a}}$ between the thickness $d$ of diode base and the carrier ambipolar diffusion length $L_{\mathrm{a}}$. Only a compromise between the reduction of $V_{\mathrm{F}}$ and the conduction of large forward currents can be obtained, and it is reached at $d / L_{\mathrm{a}}=1$ in homogenously doped PIN diodes. Therefore an appropriate density and profile of recombination defects' distribution in drift region is a promising way for improvement of the PIN diode reverse recovery characteristics. Thus, a gradual recombination defects' profile can be introduced by forming a carrier lifetime gradient correlated with diffusion one responsible for the carrier extraction speed after diode switchover.
To implement the expedient location and to change a profile of enhanced recombination layers, irradiations have been arranged by varying the energy of protons. Narrow layers of $\delta$-shape were formed by fixed-energy stopped protons within $n$-type conductivity diode base of a $p^{+}-n-n^{+}$structure, i.e. within $i$-layer of PIN diodes. Location of the $\delta$-shape layer was varied by changing the energy of protons: $2.0 \mathrm{MeV}$ protons were exploited to induce this layer close to metallurgical junction and $2.3 \mathrm{MeV}$ protons were used to position the $\delta$-shape layer in the half-width of diode base of $40 \mu \mathrm{m}$ thickness. A triangle profile with a vertex at $p^{+}-$ $n$ junction was formed by gradual step-like change of the energy of protons starting from $2.7 \mathrm{MeV}$ and going to $2.0 \mathrm{MeV}$, while fluence $\Phi$ was correspondently increased (i. e. it was the smallest for $2.7 \mathrm{MeV}$ protons). The proton irradiations were performed at University of Helsinki accelerator facilities. Several sets of industrial PIN diodes irradiated with different proton fluencies were examined. Density of radiation defects was varied by changing the irradiation fluence in the range of $7 \cdot 10^{12}-7 \cdot 10^{14} \mathrm{p} / \mathrm{cm}^{2}$. To suppress the carrier generation centres, the isochronal annealings for $24 \mathrm{~h}$ were performed by varying the heat treatment temperature in the range of $80-400^{\circ} \mathrm{C}$.

Reverse recovery time variations dependent on forward current in diodes containing a $\delta$-shape radiationinduced layer and a triangle profile of enhanced recombination region in diode base are compared in Fig. 1(a). The value of forward current in diode exhibits the density of excess carriers which should be extracted during switchover process, in this case.

Reverse recovery time $\tau_{\mathrm{RR}}$ strongly depends on the layer profile and on location of the layer containing deep recombination centres. Values of $\tau_{\mathrm{RR}}$ are decreased after using all the employed irradiation regimes relatively to the non-irradiated diodes, as shown in Fig. 1(a). In the diodes containing a $\delta$-shape $2.0 \mathrm{MeV}$ proton radiation-induced layer, the dominant recombination centres determine an increase of recombination lifetime with excitation level $\left(\sim I_{\mathrm{F}}\right)$. This type of deep centres is opposite to the desirable one, when carrier lifetime at high injection level should be shorter than that at low injection. Enhancement of irradiation fluence (of 2.0 $\mathrm{MeV}$ protons) slightly equilibrates the difference between carrier lifetimes at low $\left(\tau_{\mathrm{RL}}\right)$ and high $\left(\tau_{\mathrm{RH}}\right)$ excitation density, by reducing the $\tau_{\mathrm{RR}}$ at large $I_{\mathrm{F}} \mathrm{s}$. A shift of this $\delta$-shape radiation-induced layer towards a half-width of diode base by the increased $2.3 \mathrm{MeV}$ energy of protons improves the ratio of $\tau_{\mathrm{RH}} / \tau_{\mathrm{RL}} \rightarrow 1$. Location of a $\delta$-shape layer (induced by the same fluence 

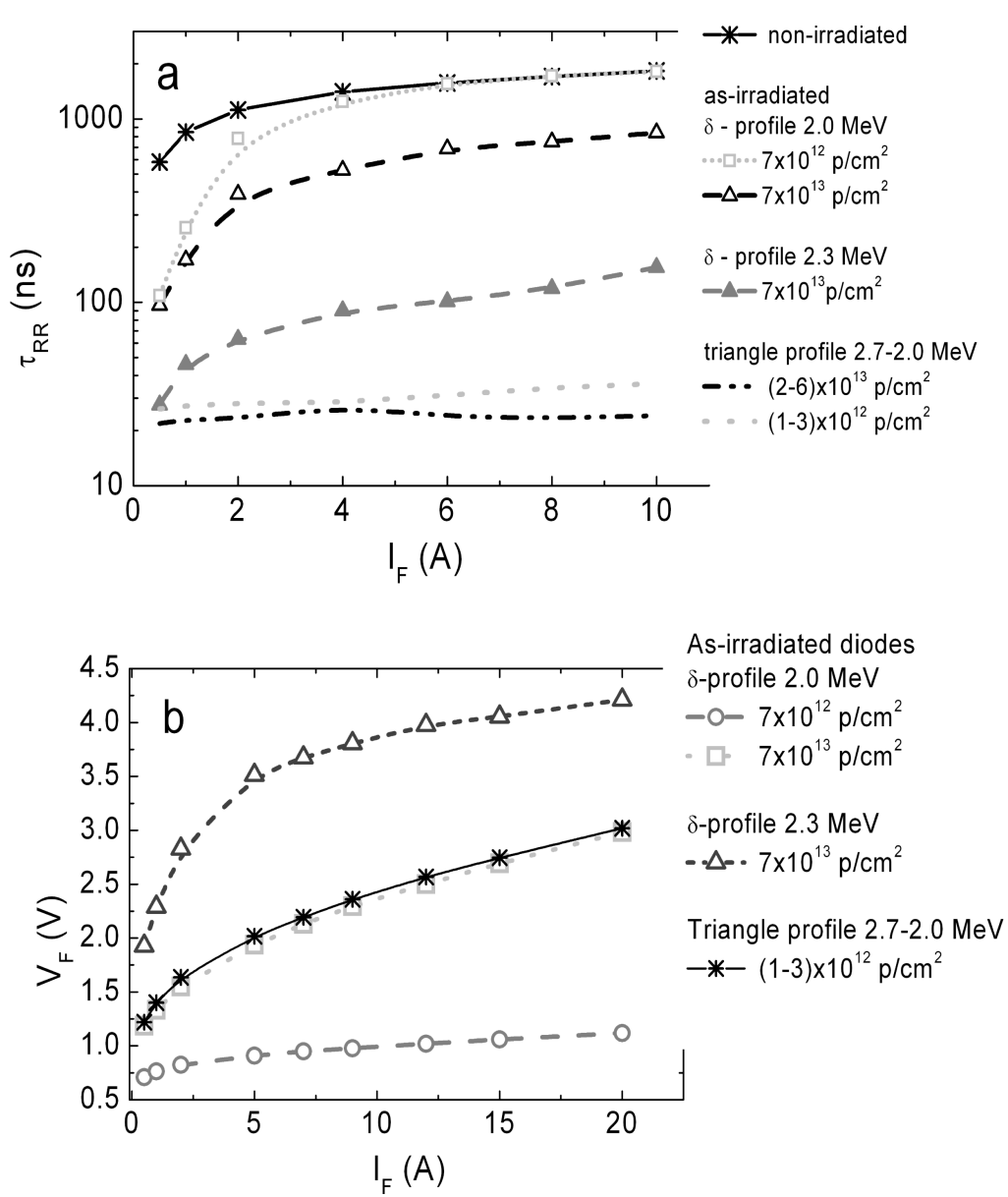

Fig. 1. (a) Reverse recovery time and (b) forward voltage drop as a function of the forward current in diodes with $\delta$-shape and triangle profiles of radiation defect distribution.

of protons) at a half-width of the diode base accelerates also the rate of diode recovery by reducing the absolute value of $\tau_{\mathrm{RR}}$, as can be deduced from the comparison of respective $\tau_{\mathrm{RR}}-I_{\mathrm{F}}$ dependences in Fig. 1(a). Formation of a triangle profile of radiation-induced recombination centres significantly improves the ratio of lifetimes approaching the desirable $\tau_{\mathrm{RH}} / \tau_{\mathrm{RL}} \leq 1$ one. Subsequently, the absolute values of $\tau_{\mathrm{RR}}$ are obtained expediently short and nearly constant. Physical reasons of the discussed variations of $\tau_{\mathrm{RR}}$ can be the competition of point-like and cluster-type radiation defects [6]. Point defects lead to a stretching of recovery time, acting as the trapping centres in forward diode operation regime. During switchover of a diode these centres become the carrier generation centres. These carrier generation centres increase the leakage current and enhance the resistivity of material.

Thus, due to these centres within a narrow $\delta$-shape layer, the forward voltage drop and distribution of reverse external applied voltage are caused. The latter is especially important when a layer of enhanced density of defects is located within a strong field area nearby the metallurgical junction. Consequently, the forward voltage drop $V_{\mathrm{F}}$ increases with irradiation fluence for all the formed defect profiles and their locations (Fig. 1(b)). The largest values of $V_{\mathrm{F}}$ are obtained for heavily irradiated $\delta$-shape layer located at the half-width of diode base. This can be explained by the increased integral resistivity of the base material over its length and by serial redistribution of forward voltage drops on junction and on elevated resistivity base, when the efficiency of carrier injection is significantly reduced. Location of a vertex of triangle profile of induced layer nearby the metallurgical junction concentrates the applied field at junction, but the enhancement of defect density over the whole width of diode base increases the integral resistivity of the base material, and, consequently, the value of $V_{\mathrm{F}}$ appears to be elevated.

Thus, the improvement of dynamic $\left(\tau_{\mathrm{RR}}\right)$ and static $\left(V_{\mathrm{F}}, I_{\mathrm{L}}\right.$ ) parameters of the PIN switchers can be reached only as a trade-off among technological procedures. Therefore, isochronous $24 \mathrm{~h}$ annealings in the temperature range of $80-400{ }^{\circ} \mathrm{C}$ have been performed in order to reduce the forward voltage drop and the leakage current. 
Deep level transient spectroscopy has been employed to identify the electrically active centres and their modifications after heat treatments.

The DLTS spectra obtained on the diodes irradiated by 2.0 and $2.3 \mathrm{MeV}$ protons containing a $\delta$-shape layer of radiation defects located either nearby the $p^{+}$ $n$ junction $(2.0 \mathrm{MeV})$ or in the half-width $(2.3 \mathrm{MeV})$ of diode base after various steps of $24 \mathrm{~h}$ isochronous annealing are illustrated in Fig. 2(a, b), respectively. The annealing temperature dependent variations of spectra are compared in Fig. 2 with those measured in the asirradiated diodes. Four main peaks in the DLTS temperature scan ranges of $90 \mathrm{~K}$, of $150-170 \mathrm{~K}$, of 180 $200 \mathrm{~K}$, and of 220-230 K appear in the DLTS spectrum of the as-irradiated diode. Several peaks are overlapped therefore the spectrum is spread into Gaussian components for more detailed analysis [2]. The dominant DLTS peaks are commonly ascribed to [7] a vacancyoxygen $\mathrm{VO}$ complex ( $E_{1}$ at $90 \mathrm{~K}$ peak), to a di-vacancy of different charged states $\left(E_{2}\right.$ at $140 \mathrm{~K} V_{2}^{=/-}$and $E_{4}$ at $230 \mathrm{~K}_{2}^{-/ 0}$ ), and to a vacancy-oxygen-hydrogen (VOH) complex [8] ( $E_{3}$ at $\left.170 \mathrm{~K}\right)$. An overlapped peak in the scan temperature range of $160-200 \mathrm{~K}$ is debated $[9,10]$ as a trap associated with clusters. Protons of energy $<10 \mathrm{MeV}$ due to the large interaction cross-section create defects efficiently within a stopping range. High density of stopped protons $\mathrm{H}^{+}$is a reason for intense generation of the $\mathrm{VOH}$ complexes within a stopping range $[11,12]$. Therefore, the latter $E_{3}$ peak dominates in the DLTS spectrum (Fig. 2(a)) measured for the asirradiated diode containing a $\delta$-shape layer of radiation defects located nearby the $p^{+}-n$ junction. Shift of the $\delta$-shape layer towards a half-width of diode base does not change the structure of dominant DLTS peaks, however, one observes a reduction of the amplitude of the $E_{3}$ peak (Fig. 2(b)) relatively to the di-vacancy ascribed $\left(E_{2}, E_{4}\right)$ peaks. This result implies that a depth integrated DLTS signal exposes an enhanced role of irradiated pedestal of defects relatively to a narrow $\delta$-shape layer which prevails in the DLTS spectrum measured

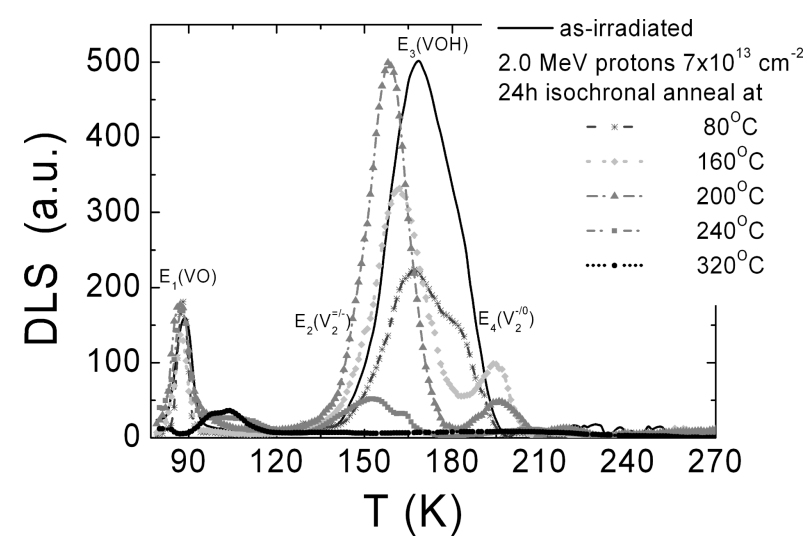

(a)

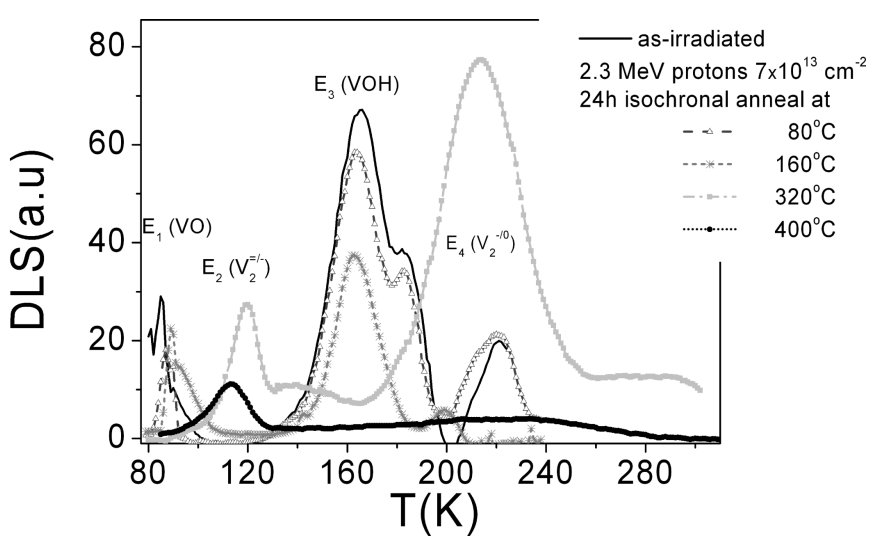

(b)

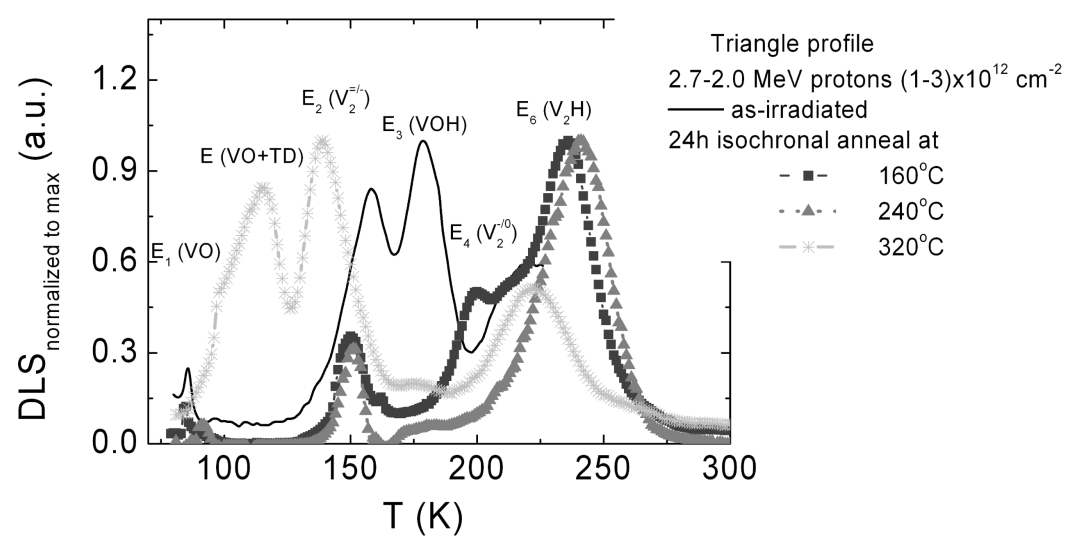

(c)

Fig. 2. Transforms of the DLTS spectra measured on diodes containing a radiation-induced (a,b) $\delta$-shape and (c) triangle profile of defect distribution after various steps of $24 \mathrm{~h}$ isochronal annealing. Annealing dependent variations of spectra for traps of majority carriers are compared with those measured in the as-irradiated diode. 
for the as-irradiated diode (by $2 \mathrm{MeV}$ protons). This clearly shows that VOH complexes are dominant within the stopping range of protons. In diodes containing a triangle profile of defect distribution, the overlapped multi- $\delta$-shape layers are formed by the gradual step-like change of proton energy. Consequently, the VOH complexes are dominant in each layer, and $E_{3}$ peak again dominates in the DLTS spectrum (Fig. 2(c)) of the asirradiated diode containing a triangle profile of defects.

A seeming shift of peaks appears after each heating step in both irradiation profiles containing diodes. Actually, these shifts are determined by variation of different overlapping peaks. In diodes with a $\delta$-shape layer the most significant changes are observed at $E_{3}$ peak associated with $\mathrm{VOH}$ complexes. Amplitude of this peak rapidly decreases with enhancement of annealing temperature. Reduction of this peak is correlated with slight increase of amplitude of the $E_{1}$ peak and with significant enhancement of di-vacancy ascribed peaks $E_{2}$ and $E_{4}$.

Correlated decrease of density of the VOH complexes, detected as a reduction of $E_{3}$ peak's amplitude, with non-monotonous variations of the $E_{1}$ peak associated with VO complex and with significant enhancement of intensities of both $E_{2}$ and $E_{4}$ peaks, indicates an efficient annealing of the $\mathrm{VOH}$ complexes. Then, a VOH decay component VO may be responsible for the changes of $E_{1}$ peak intensity. Additionally, vacancies arising as a product of VOH complex decay seem to be rapidly joined into di-vacancies. This can be a reason for significant increase of amplitudes of $E_{2}$ and of $E_{4}$ peaks with heat treatment temperature. Further enhancement of the annealing temperature leads to the more complicated changes of $E_{2}$ and $E_{4}$ peaks. The latter can be explained by exhausting of density of the initially created $\mathrm{VOH}$ complexes. Qualitatively similar

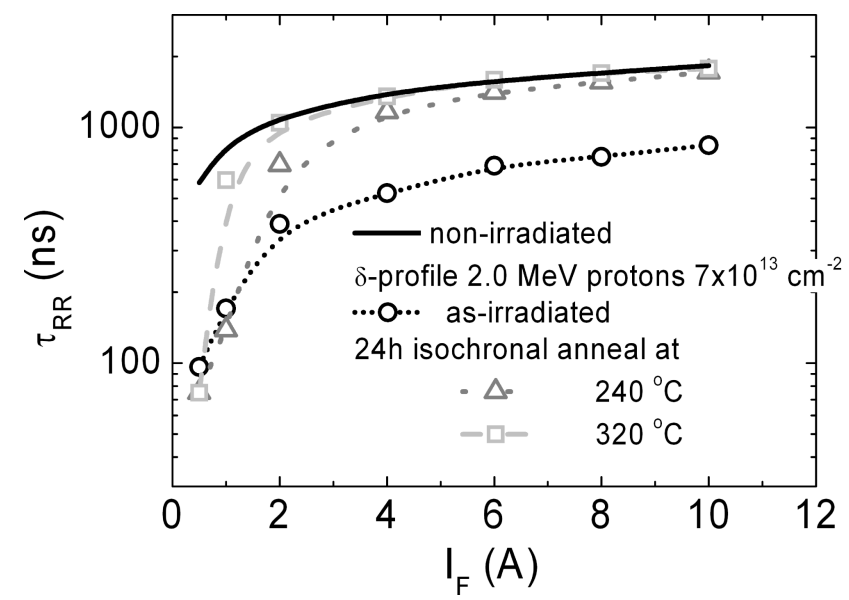

(a)

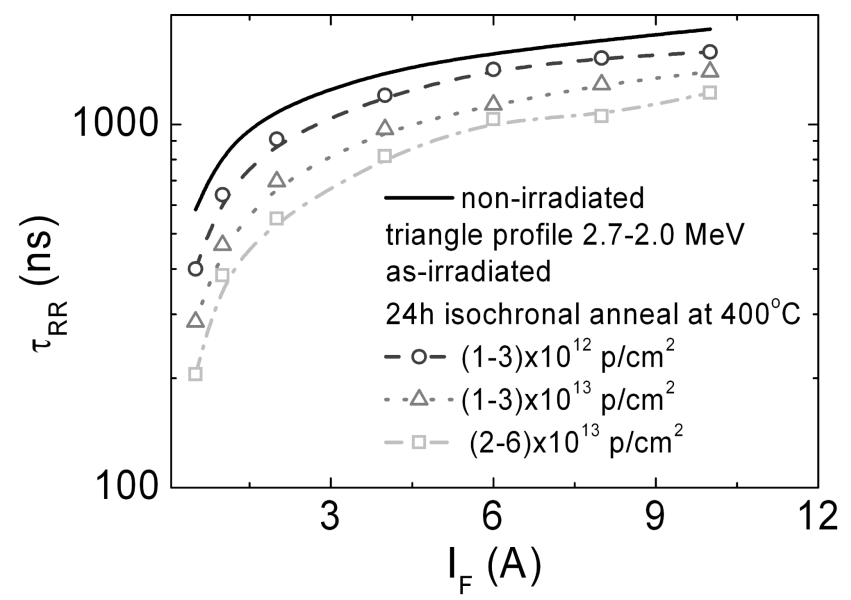

(b)

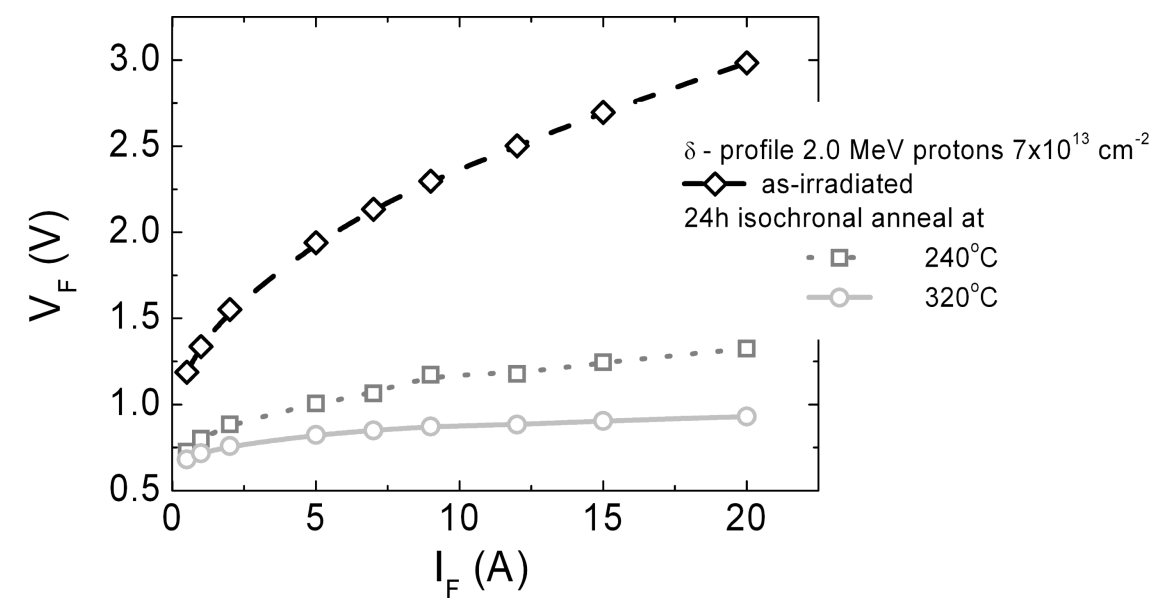

(c)

Fig. 3. (a, b) Reverse recovery time and (c) forward voltage drop as a function of forward current. These characteristics are compared for PIN diodes containing either the $(\mathrm{a}, \mathrm{b}) \delta$-shape or (b) triangle profile of irradiation defect distribution. Variations of these characteristics obtained by varying the heat treatment temperature are compared with those measured in the same non-irradiated and as-irradiated PIN diodes. 
picture of the heat treatment-induced transforms of the DLTS spectra has been also observed for diodes containing a triangle profile of defect distribution. Here, a slight difference relatively to diodes with $\delta$-shape layer can be revealed within a wing of elevated scan temperatures of DLTS spectra. An additional hydrogen related complex $\left(E_{5}\right)$ can be resolved via annealing dependent variations of an amplitude of DLTS signal within a range of the $E_{4}$ peak. An origin of this $E_{5}$ peak is debated as being associated with di-vacancy-hydrogen $\left(\mathrm{V}_{2} \mathrm{H}\right)$ complex [7,13]. Appearance of the latter $E_{5}$ peak in diodes with the triangle defect distribution profile can be explained by a decay scenario of dense area of $\mathrm{VOH}$ complexes within the base area, when creation of $\mathrm{V}_{2} \mathrm{H}$ complexes is preferable relatively to pure divacancies due to weaker escape of hydrogen. This decay scenario also gives rise to an elevated density of VO complexes. Enhancement of density of VO complexes is corroborated by significant increase of a spectrum band ascribed to shallow levels within a wing of low DLTS scan temperatures.

For PIN diodes, both with a $\delta$-shape layer $(2 \mathrm{MeV}$ protons) and containing a triangle profile (gradually varied energy $2.7-2.0 \mathrm{MeV}$ of protons) created with average fluence of $7 \cdot 10^{13} \mathrm{p} / \mathrm{cm}^{2}$, the reverse recovery time $\tau_{\mathrm{RR}}$ increases after each step of $24 \mathrm{~h}$ heat treatment, as illustrated in Fig. 3(a). After final (in this investigation) $400{ }^{\circ} \mathrm{C}$ annealing step, the value of $\tau_{\mathrm{RR}}$ at elevated injection levels $\left(\sim I_{\mathrm{F}}\right)$ in diodes containing a $\delta$-shape layer is almost completely restored to that measured in the non-irradiated diode, Fig. 3(a). In diodes containing a triangle profile of defect distribution along the base (Fig. 3(b)), irradiated by the smallest fluence, $\tau_{\text {RR }}$ is also restored to that measured in the non-irradiated diode. However, for diodes irradiated by larger fluences, the restoration of $\tau_{\mathrm{RR}}$ values is incomplete, and restoration level depends on irradiation fluence. In addition, $\tau_{\mathrm{RR}}$ in heat treated diodes becomes to be dependent on injection level, as shown in $\tau_{\mathrm{RR}}-I_{\mathrm{F}}$ plots for as-irradiated and heat treated diodes, Fig. 3(b). The observed variations of $\tau_{\mathrm{RR}}-I_{\mathrm{F}}$ characteristic can be explained by different impact of point-like complexes and of extended clusters. The revealed decay of the pointlike VOH complexes (in DLTS spectra) determines the high injection level carrier recombination lifetime $\tau_{\mathrm{RH}}$, due to change of type of the dominant deep centres. The re-arrangement of a space-charge sphere (surrounding cluster) during heat treatments causes a redistribution of carriers and a limited filling of deep centres. Consequently, carrier lifetime $\tau_{\mathrm{RL}}$ at low densities of injected carriers is shortened.
The forward voltage drop $V_{\mathrm{F}}$ decreases after each temperature step of employed heat treatments, as illustrated in Fig. 3(c). However, values of $V_{\mathrm{F}}$ in the annealed diodes do not reach that value in the nonirradiated ones. Although, the observed $V_{\mathrm{F}}$ reduction shows a beneficial impact of annealings in the correction of static parameters of the irradiated PIN diodes. The revealed behaviour can be explained by radiationand heat treatment-induced variations of resistivity of the base region material. Annealings determine a reduction of this resistivity, and, subsequently of $V_{\mathrm{F}}$ values.

\section{Summary}

Reverse recovery time $\tau_{\mathrm{RR}}$ strongly depends on the layer profile and on location of the layer containing deep recombination centres. Formation of a $\delta$-shape layer enables to get the fastest $1 / \tau_{\mathrm{RR}}$ switching rate of PIN diodes. Formation of a triangle profile of radiation-induced recombination centres significantly improves the ratio of lifetimes by approaching the desirable $\tau_{\mathrm{RH}} / \tau_{\mathrm{RL}} \leq 1$ value. Point radiation defects lead to a stretching of recovery time, acting as the trapping centres in forward diode operation regime. During switchover of a diode these centres become the carrier generation centres. These centres are responsible for increase of the leakage current $I_{\mathrm{L}}$ and enhancement of the resistivity of material. Consequently, forward voltage drop $V_{\mathrm{F}}$ increases with irradiation fluence for all the formed defect profiles and their locations. The largest values of $V_{\mathrm{F}}$ are obtained for heavily irradiated $\delta$-shape layer located at the half-width of diode base. Therefore, improvement of dynamic $\left(\tau_{\mathrm{RR}}\right)$ and of static $\left(V_{\mathrm{F}}, I_{\mathrm{L}}\right)$ parameters of the PIN switchers can be reached only as a trade-off among irradiation and heat treatment technological procedures. $\mathrm{VOH}$ complexes are dominant within the stopping range of protons in the as-irradiated diodes. Isochronous $24 \mathrm{~h}$ heat treatments of the irradiated diodes in temperature range of $80-400{ }^{\circ} \mathrm{C}$ indicate an efficient annealing of the $\mathrm{VOH}$ complexes by transforms to other di-vacancy associated deep centres. Value of $\tau_{\mathrm{RR}}$ at elevated injection levels $\left(\sim I_{\mathrm{F}}\right)$ in diodes containing a $\delta$-shape layer is almost completely restored to that measured in the non-irradiated diode. At the smallest irradiation fluence, in diodes containing a triangle profile of defect distribution along the base, $\tau_{\mathrm{RR}}$ is also restored to that measured in the non-irradiated diode. For these diodes irradiated by larger fluences, the restoration of $\tau_{\mathrm{RR}}$ values is incomplete, and restoration level depends on irradiation fluence. The observed 
variations of $\tau_{\mathrm{RR}}-I_{\mathrm{F}}$ characteristic can be explained by modification through annealing and separate impact of point-like complexes and of clusters. The observed $V_{\mathrm{F}}$ reduction shows a beneficial impact of annealings in the correction of static parameters of irradiated PIN diodes. The revealed behaviour can be explained by radiation and heat treatment-induced variations of resistivity of the base region material.

\section{References}

[1] B.J. Baliga, Power Semiconductor Devices (PWS Publishing Company, Boston, 1996).

[2] E. Gaubas, T. Čeponis, A. Uleckas, J. Vaitkus, and J. Raisanen, Recombination characteristics in $2-3 \mathrm{MeV}$ protons irradiated FZ Si, Nucl. Instrum. Methods A 612, 559-562 (2010).

[3] P. Hazdra and V. Komarnitskyy, Lifetime control in silicon power P-i-N diode by ion irradiation: Suppression of undesired leakage, Microelectron. J. 37, 197-203 (2006).

[4] I. Pintilie, E. Fretwurst, G. Lindstroem, and J. Stahl, Results on defects induced by ${ }^{60} \mathrm{Co}$ gamma irradiation in standard and oxygen-enriched silicon, Nucl. Instrum. Methods A 514, 18-24 (2003).

[5] J. Višniakov, E. Gaubas, T. Čeponis, A. Uleckas, J. Raisanen, and S. Vayrynen, Comparative investigation of recombination characteristics in proton and electron irradiated Si structures, Lithuanian J. Phys. 48, 137-144 (2008).

[6] T. Čeponis, A. Balčytis, A. Dzimidavičius, E. Gaubas, and J. Kusakovskij, Variations of the electrical charac- teristics in proton irradiated silicon PIN diodes, Lithuanian J. Phys. 50, (this issue) (2010).

[7] K. Bonde Nielsen, L. Dobaczewski, and K. Goscinski, Deep levels of vacancy-hydrogen centers in silicon studied by Laplace DLTS, Physica B 167, 273-274 (1999).

[8] I. Pintilie, M. Buda, E. Fretwurst, F. Hönniger, G. Lindström, and J. Stahl, Radiation-induced donor generation in epitaxial and $\mathrm{Cz}$ diodes, Nucl. Instrum. Methods A 552, 56-60 (2005).

[9] P. Johannesen, B. Bech Nielsen, and J.R. Byberg, Identification of the oxygen-vacancy defect containing a single hydrogen atom in crystalline silicon, Phys. Rev. B 61, 4659-4666 (2000).

[10] K. Gill, G. Hall, and B. MacEvoy, Bulk damage effects in irradiated silicon detectors due to clustered divacancies, J. Appl. Phys. 82, 126-136 (1997).

[11] P. Lévêque, P. Pellegrino, A. Hallén, B.G. Svensson, and V. Privitera, Hydrogen-related defect centers in float-zone and epitaxial $n$-type proton implanted silicon, Nucl. Instrum. Methods B 174, 297-303 (2001).

[12] M. Mikelsen, E.V. Monakhov, G. Alfieri, B.S. Avset, J. Härkönen, and B.G. Svensson, Annealing of defects in irradiated silicon detector materials with high oxygen content, J. Phys. Condens. Matter 17, 2247-2253 (2005).

[13] P. Johannesen, R. Jakobsen, P. Stallinga, B. Bech Nielsen, and J.R. Byberg, Silicon vacancy containing two hydrogen atoms studied with electron paramagnetic resonance and infrared absorption spectroscopy, Phys. Rev. B 66, 235201 (2002). 


\title{
PROTONAIS ŠVITINTŲ IR IŠKAITINTŲ Si PIN DIODŲ PERJUNGIMO IR KRŪVININKŲ REKOMBINACIJOS CHARAKTERISTIKŲ TYRIMAS
}

\author{
A. Uleckas, T. Čeponis, A. Dzimidavičius, E. Gaubas, J. Pavlovas, K. Žilinskas \\ Vilniaus universiteto Taikomuju mokslu institutas, Vilnius, Lietuva
}

\begin{abstract}
Santrauka
Galios PIN diodų bazèje buvo formuojami $\delta$ arba trikampio pavidalo radiacinių defektu pasiskirstymo profiliai diodų persijungimui spartinti. $\delta$ pavidalo padidintos rekombinacijos sluoksnis buvo formuojamas švitinant fiksuotos 2,0 bei $2,3 \mathrm{MeV}$ protonų energijos pluošteliu, o trikampio pavidalo radiacinių defektų pasiskirstymo profilis buvo sudaromas laipsniškai keičiant protonų įtėkį ir energiją 2,7-2,0 MeV intervale. Radiaciniu defektų tankis buvo keičiamas varijuojant apšvitos įtèki $10^{13}-10^{15} \mathrm{~cm}^{-2}$ intervale, krūvininkų rekombinacijos trukmès ir diodų perjungimo spartos valdymui. Buvo aptiktas ryškus krūvininkų rekombinacijos trukmès $\tau_{\mathrm{R}}$ ir PIN diodų perjungimo trukmès $\tau_{\mathrm{RR}}$ sutrumpèjimas po diodų apšvitos protonais. Tačiau kartu išauga diodo nuotèkio srove $I_{\mathrm{L}}$ ir tiesioginio jungimo įtampos kritimas $V_{\mathrm{F}}$. Ivertinta švitinant sudaryto sluoks-
\end{abstract}

nio profilio bei padèties diodo bazeje ittaka statiniams $\left(I_{\mathrm{L}}, V_{\mathrm{F}}\right)$ ir dinaminiams $\left(\tau_{\mathrm{RR}}\right)$ prietaiso parametrams. Siekiant sumažinti apšvita sukurtų taškinių krūvininkų generacijos centrų nulemtą diodo nuotėkio srovès bei tiesioginès įtampos kritimo išaugimą, diodai buvo $24 \mathrm{~h}$ izochroniškai iškaitinti $80-400{ }^{\circ} \mathrm{C}$ temperatūroje. Palyginant užregistruotus giliụjų lygmenų (DLTS) spektrus po apšvitos ir po iškaitinimų, aptiktas žymus vakansijos-deguonies-vandenilio (VOH) taškiniam kompleksui priskirtinos DLTS smailès amplitudès mažejimas. Sinchroniškai išauga divakansiniams $V_{2}^{=/-,-/ 0}$ kompleksams priskirtinų smailių amplitudè DLTS spektre po iškaitinimų. VOH ir $V_{2}^{=/-,-/ 0}$ taškinių bei sankaupinių radiacinių defektų susikūrimas po apšvitos $2,0-2,7 \mathrm{MeV}$ protonais leidžia valdyti diodo $\tau_{\mathrm{RR}}$ trukmes, o VOH centru iškaitinimas leidžia sumažinti $V_{\mathrm{F}}$ itampos kritima. 